\title{
Severe anorectal injury caused by a jet ski accident: report of a case
}

\author{
Takeshi Tatsuta, Kenji Okumura, Tomoharu Shimizu, Eiji Mekata \\ Satoshi Murata, Hiroshi Yamamoto, Tohru Tani
}

\begin{abstract}
We report a case of severe anorectal injury caused by a jet ski accident. An 18-year-old girl riding on the back of a craft fell backward from the seat when the craft was suddenly accelerated. Her buttocks closely opposed the water jet nozzle of the craft as she entered the water. Afterward, she had severe perianal and abdominal pain. Two posterior anorectal tears were observed on physical examination. An abdominal CT scan revealed free air and ascites in the abdominal cavity and presacral space. A perforation of the anterior rectal wall was detected during an emergency operation. The perforated rectal wall and posterior sphincter muscles were sutured and a diverting sigmoid colostomy was made. She was discharged from our hospital 24 days after the surgery without any complication. Her diverting colostomy was closed six months later. Her anal function was almost perfectly preserved. Reports of severe traumatic injuries caused by jet ski accidents are increasing. Hence, wearing of a wet suit is recommended for not only the driver but also passengers during personal watercraft operation. Injury prevention education and government regulation for the drivers should also be considered to avoid traumatic injury from jet skis.
\end{abstract}

(JJAAM 2009; 20: 232-6)

Keywords: colorectal perforation, anal injury, colostomy, sepsis, peritonitis

Received on December 5, 2008 (08-091)

\section{Case Report}

Jet skis or personal watercrafts have become popular in Japan. Accordingly, accidents or injuries involving jet skis have been increasing. We report the extremely rare case of an 18-year-old woman who received a severe anorectal injury caused by the propulsion system of a jet ski.

Two passengers with a driver were riding on a tandemtype personal jet ski in a lake. A passenger on the tail end fell backward from the rear seat when the craft was suddenly accelerated. Her buttocks closely opposed the water jet nozzle of the craft. She sensed that the jet water forcefully hit her anus and entered her rectum. Thereafter, she complained of perianal and abdominal pain. When she was transferred to our hospital, her initial vital signs were

Corresponding author:

Tomoharu Shimizu, Assistant Professor,

Department of Surgery, Shiga University of Medical Science

Seta-tsukinowacho, Otsu, Shiga, 520-2192, Japan

Phone: +81-77-548-2238 Fax: +81-77-548-2240

E-mail: tomoharu@belle.shiga-med.ac.jp stable. Physical examination revealed a rigid abdomen with rebound tenderness and abdominal guarding. Two lacerations of the posterior anal verge and perianal ecchymosis, but no obvious gynecological injuries, were observed (Fig. 1). Digital examination demonstrated negligible sphincter tone. Anorectoscopy revealed two 5 -cm tears in the posterior wall of the rectum including the anal verge to the anal sphincter muscle. The white blood cell count was $16,300 / \mathrm{mm}^{3}$. An abdominal CT scan revealed free air and ascites in the peritoneal cavity (Fig. 2a) and the pre-rectal and presacral spaces (Fig. $2 \mathbf{b}$ and $\mathbf{2 c}$ ).

An emergent laparotomy through a lower abdominal median incision was performed 6 hours after the accident. There was a large amount of dirty ascites including lake water in the abdominal cavity. All intestines showed marked edema with reddish serosa due to the fresh water of the lake. A 3-cm perforation of the anterior rectal wall above the peritoneal reflection was observed (Fig. 3a). The anterior rectal perforation was primarily closed by two layers (Fig. 3b). The proximal colon was diverted and a single barrel sigmoid colostomy was performed. The lacerated anal sphincter muscle of the posterior wall was transiently sutured without closure of mucosa for the repair of 


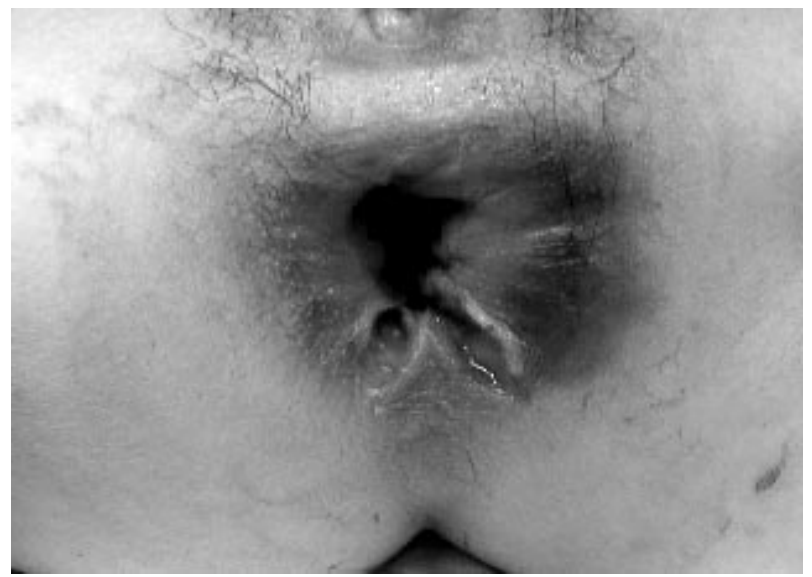

Fig. 1. Posterior perianal lacerations and ecchymosis but no obvious vaginal injuries are detected.
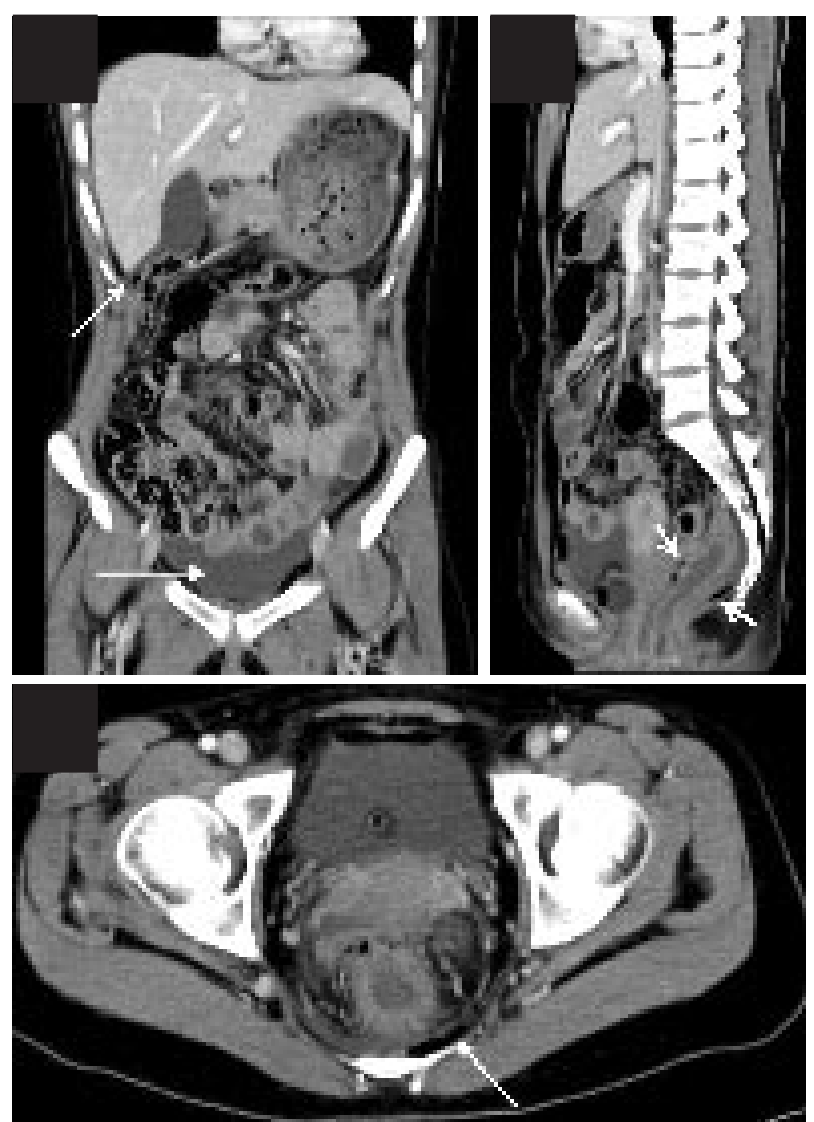

\begin{tabular}{l|lll} 
a & b & Fig. 2. Abdominal CT scan demonstrates free air
\end{tabular} and ascites in the peritoneal cavity (a, arrows), in the pre-rectal space (b, arrows), and the pre-sacral space (c, arrows).
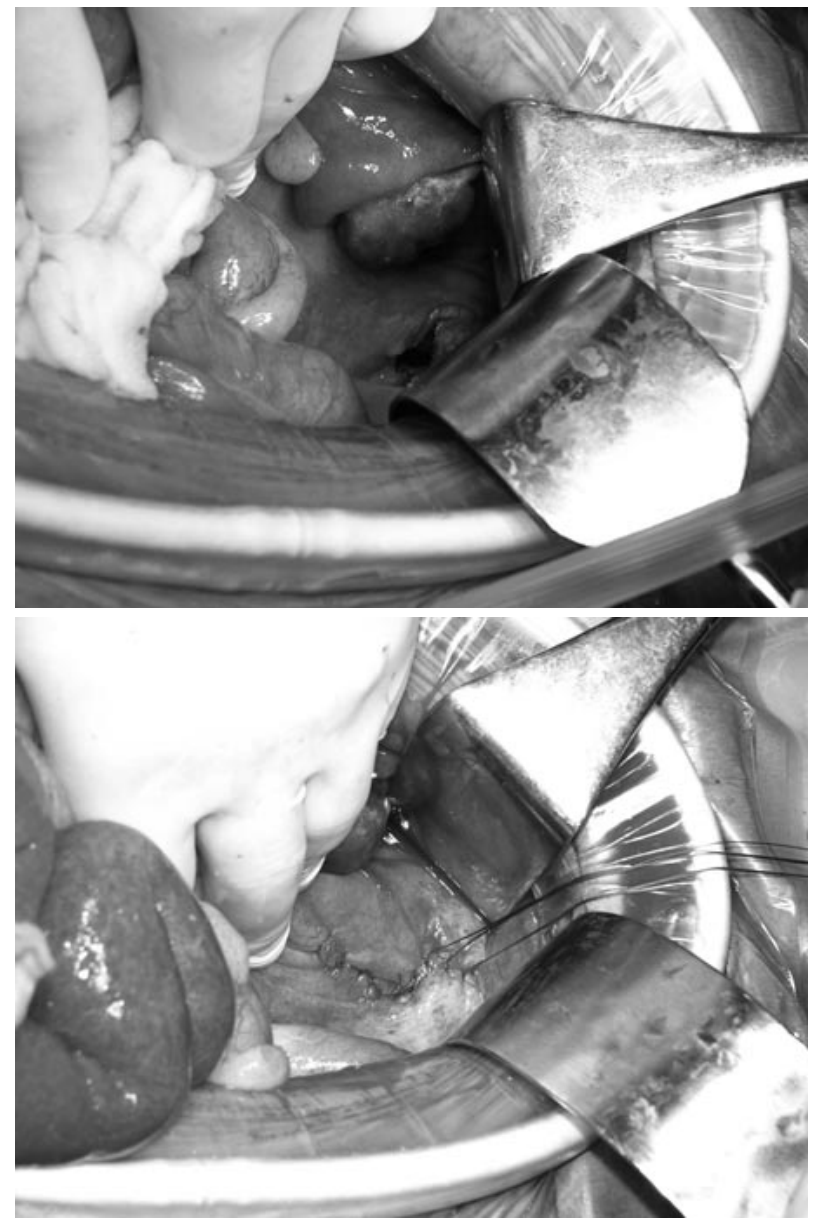

$\frac{\mathbf{a}}{\mathbf{b}}$

Fig. 3. A $3 \times 3 \mathrm{~cm}$ perforation of the anterior wall of the rectum above the peritoneal reflection is shown (a). The rectal perforation was debrided and closed in two layers (b).

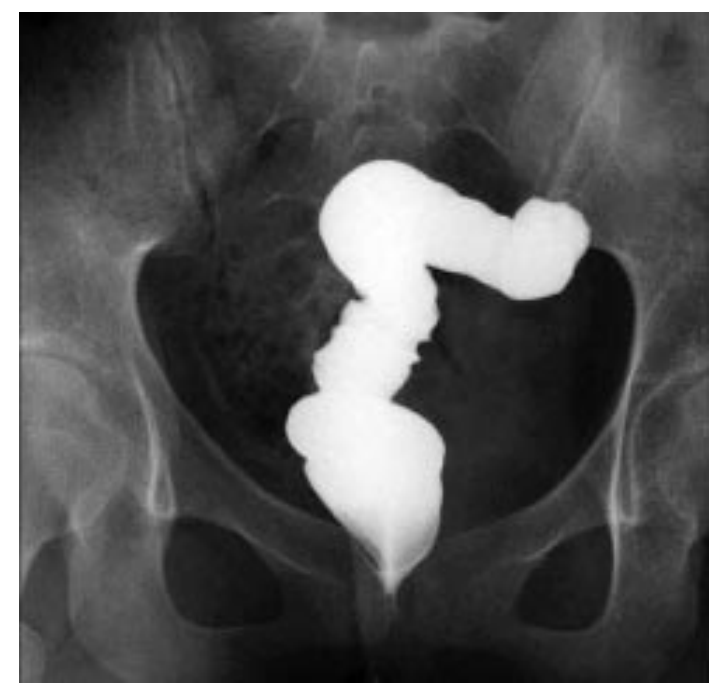

Fig. 4. An intestinal enema with liquid contrast media reveals no leakage into the peritoneal cavity or the pelvic space. 
Table 1. Reported cases of anorectal injury related to jet skis.

\begin{tabular}{|c|c|c|c|c|c|c|}
\hline $\begin{array}{l}\text { Reference } \\
\text { number }\end{array}$ & $\begin{array}{l}\text { Published } \\
\text { year }\end{array}$ & Age/Sex & Injured part & Operation method & Prognosis & $\begin{array}{l}\text { Anorectal } \\
\text { sphincter } \\
\text { functions }\end{array}$ \\
\hline 6 & 1998 & $\begin{array}{l}14 \text { y } \\
\text { female }\end{array}$ & $\begin{array}{l}5 \text { to } 10 \mathrm{~cm} \text { tear to dentate line } \\
\text { in rectum; blow-out in rec- } \\
\text { tosigmoid colon. }\end{array}$ & $\begin{array}{l}\text { Resection of injured rectum, } \\
\text { irrigation, drainage, single } \\
\text { barrel colostomy }\end{array}$ & alive & $\begin{array}{l}\text { not } \\
\text { described }\end{array}$ \\
\hline 7 & 1999 & $\begin{array}{l}15 y \\
\text { female }\end{array}$ & $\begin{array}{l}1 \times 8 \mathrm{~cm} \text { perforation in ante- } \\
\text { rior wall of rectum above } \\
\text { peritoneal reflection }\end{array}$ & $\begin{array}{l}\text { Primarily closure of injured } \\
\text { wall, irrigation, drainage, } \\
\text { proximal diverting colostomy }\end{array}$ & alive & normal \\
\hline 8 & 1999 & $\begin{array}{l}30 y \\
\text { female }\end{array}$ & $\begin{array}{l}4 \mathrm{~cm} \text { tear in posterior rectum } \\
(12 \mathrm{~cm} \text { from anal verge })\end{array}$ & $\begin{array}{l}\text { Loop colostomy, irrigation } \\
\text { and drainage }\end{array}$ & alive & normal \\
\hline 9 & 2003 & $\begin{array}{l}16 \mathrm{y} \\
\text { male }\end{array}$ & $\begin{array}{l}5 \mathrm{~cm} \text { laceration in anterior wall } \\
\text { of sigmoid colon (surgery), } \\
\text { anterior rectal mucosal wall } \\
\text { (autopsy) }\end{array}$ & $\begin{array}{l}\text { Primarily closure of injured } \\
\text { wall }\end{array}$ & dead & $\begin{array}{l}\text { not } \\
\text { described }\end{array}$ \\
\hline 10 & 2007 & $\begin{array}{l}28 \text { y } \\
\text { female }\end{array}$ & Anorectal rupture & $\begin{array}{l}\text { Sutured primarily, double } \\
\text { loop colostomy }\end{array}$ & alive & normal \\
\hline $\begin{array}{l}\text { Present } \\
\text { case }\end{array}$ & 2009 & $\begin{array}{l}18 \text { y } \\
\text { female }\end{array}$ & $\begin{array}{l}5 \mathrm{~cm} \text { tear in posterior anorec- } \\
\text { tal wall, } 3 \mathrm{~cm} \text { perforation of } \\
\text { recto-sigmoid colon }\end{array}$ & $\begin{array}{l}\text { Primarily closure of injured } \\
\text { wall in recto-sigmoid colon, } \\
\text { suture of anal sphincter muscle } \\
\text { in posterior rectal wall, irriga- } \\
\text { tion, drainage, single barrel } \\
\text { colostomy }\end{array}$ & alive & $\begin{array}{l}\text { almost } \\
\text { normal }\end{array}$ \\
\hline
\end{tabular}

the posterior wall of the rectum.

The patient did not have any complications after the operation. The digital examination before leaving the hospital found that her anal sphincter tone was weak but steady. An intestinal enema with liquid contrast media administered 3 weeks after surgery revealed no leakage into the peritoneal cavity or the pelvic space. She was able to keep liquid contrast media in the rectum by herself (Fig. 4). Her colostomy was closed 6 months after the initial injury. Anorectal manometry was performed with a Heritron (Cardio Design pty Ltd., Oalkeigh, Australia) 6 months after the second surgery. Her average anal pressure was $44 \mathrm{~cm} \mathrm{H}_{2} \mathrm{O}$ and maximum squeeze pressure was $71 \mathrm{~cm} \mathrm{H} \mathrm{H}_{2} \mathrm{O}$. Although she sometimes experiences fecal incontinence at night, she subsequently had return of almost normal bowel function.

\section{Discussion}

Personal watercraft and jet skis have become increasingly popular since their introduction in 1974. As the user population of jet skis has increased, the incidence of injury related to personal watercraft accidents has also in- creased. The majority of these injuries are caused by collisions with bridges, docks, or other watercraft. The reported injuries have ranged from lacerations and fractures to more serious head trauma or death ${ }^{1,2}$.

Previous case reports have described vaginal trauma caused by the water jets of personal watercraft ${ }^{3-5}$. Recently, there have been five published reports of anorectal injury without vaginal trauma caused by jet ski accidents ${ }^{6-10)}$. A highly similar pattern of injury has also been observed in water-skiing accidents. Kizer ${ }^{11)}$ described this type of injury as being due to the forceful entry of water under high pressure into any orifices of the body. As shown in Table 1 , all but one case were young females. The male patient, in whom the injured anterior wall of the sigmoid colon was primarily sutured by two layers without colostomy, died. In four cases, the sites of perforation in the peritoneal cavity were above the peritoneal reflection and around the rectosigmoid junction. Taking into consideration these cases, the high velocity water impacts may cause perforation in the anterior wall of the rectum above the peritoneal reflection where the wall is relatively weak compared to the rectum that is fixed to the pelvic cavity. To our knowledge, we report a rare case of anorectal trauma caused by 
a personal jet ski accident that involves perforation in the pelvic space as well as in the peritoneal cavity (Table 1).

The traditional principles of colo-rectal trauma management include a diverting colostomy, antibiotic treatment, and pre-sacral or intra-abdominal drainage ${ }^{12}$. Previous studies reported that primary anastomosis of the unprepared left colon is safe in most urgent and emergency situations ${ }^{13)}$. However, for our patient, a colostomy was considered necessary to divert feces away from the sutured wound of the rectum and also from the large laceration in the pre-sacral cavity. We selected a single barrel colostomy rather than the loop colostomy of sigmoid or transverse colon since all the intestines had marked edema and swelling due to fresh water. Another reason to select a single barrel colostomy was the high probability of a permanent colostomy due to loss of anal function resulting from extremely severe injury of anal sphincter muscles.

Another issue for these patients is fecal incontinence. Shatari et al. ${ }^{14)}$ reported that internal sphincter injury and reduced anal sphincter pressure were related to the level of incontinence in women with third degree obstetric anal sphincter injury repaired at the time of delivery. Fortunately, although our patient sometimes encounters fecal incontinence at night, she has had return of almost normal bowel function.

The prevention of accidents and injuries related to jet skis should be a primary goal for users. Perianal injury victims were all passengers who fell off the back of a personal watercraft while the driver continued to activate the throttle lever. Most models of jet skis provide a cord attachment from the driver to the ignition key of the craft that can shut off the machine's engine upon ejection of the driver from the craft. It should be noted, however, that no such emergency cord is attached to passengers. This point may explain why all victims were passengers. Moreover, in this case, our patient was only wearing a twopiece swimming suit. Since there are no reported cases of perianal or rectal water jet injuries occurring with the use of a wet suit, wearing of a wet suit is recommended for not only the driver but also passengers during personal watercraft operation to provide protection against traumatic high velocity water impact. Effective public safety educa- tion and government regulation for the drivers of jet skis should also be considered to avoid preventable traumatic injury from jet skis.

\section{References}

1) Hamman BL, Miller FB, Fallat ME, et al: Injuries resulting from motorized personal watercraft. J Pediatr Surg 1993; 28: $920-2$.

2) Swinburn EE: Serious injuries in jet skiers. Med J Aust 1996; 165: 606-9.

3) Wein P, Thompson DJ: Vaginal perforation due to jet ski accident. Aust N Z J Obstet Gynaecol 1990; 30: 384-5.

4) Haefner HK, Andersen HF, Johnson MP: Vaginal laceration following a jet-ski accident. Obstet Gynecol 1991; 78: 9868.

5) Muller RJ: Jet-ski injury: a case history. J La State Med Soc 1993; 145: 27-8.

6) Morrison DM, Pasquale MD, Scagliotti CJ: Hydrostatic rectal injury of a jet ski passenger: case report and discussion. J Trauma 1998; 45: 816-8.

7) Philpott JM, Ng PC, Wixon CL, et al: Rectal blowout by personal watercraft water jet: case report and review of literature. J Trauma 1999; 47: 385-8.

8) Parsons DP, Kahn HA, Isler JT, et al: Rectal injury caused by a personal watercraft accident: report of a case. Dis Colon Rectum 1999; 42: 959-60.

9) Descottes B, Lachachi F, Moumouni I, et al: Rectal injury caused by personal watercraft accident: report of a case. Dis Colon Rectum 2003; 46: 971-3.

10) Nieboer TE, Assmann RF, Withagen MI, et al: Anorectal injury after a fall from a jet ski. Ned Tijdschr Geneeskd 2007; 151: 2333-6.

11) Kizer KW: Medical hazards of the water skiing douche. Ann Emerg Med 1980; 9: 268-9.

12) Corman ML: Colon and rectal surgery. 3rd ed. JB Lippincott, Philadelphia, 1993: 250-1.

13) Trillo C, Paris MF, Brennan JT: Primary anastomosis in the treatment of acute disease of the unprepared left colon. Am Surg 1998; 9: 821-4.

14) Shatari $T$, Hayes J, Pretlove $S$, et al: Importance of evacuatory disturbance in evaluation of faecal incontinence after third degree obstetric tear. Colorectal Dis 2005; 7: 18-21. 
症例報告

\section{ジェットスキー事故による重症肛門直腸傷害の 1 例}

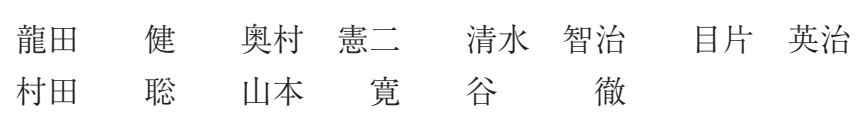

要旨 ジェットスキー事故により生じた重傷肚門直腸損傷の 1 例を経験したので報告する。後部座席に乗車中の 18歳女性が突然加速により座席後方へ後ろ向きに転落した。着水時に殿部がジェット水流排出口に近接する状態 となった。患者は強い肛門周囲痛と腹痛を訴え，2箇所の肛門直腸裂創が確認された。腹部CTでは腹腔内と仙骨 前面腔に遊離ガスと腹水を認めた。緊急開腹手術にて直腸前壁の穿孔を認めたため, 直腸穿孔部と直腸後壁括約 筋を一期的に縫合し, S状結腸人工肛門を造設した。術後24日目に患者は合併症なく退院した。人工肛門は 6 か 月後に閉鎖され肛門機能はほぼ完全に保たれた。ジェットスキーにより引き起こされる重傷損傷は増加しており， ジェット水流による外傷の予防には運転者だけでなく同乗者にもウエットスーツ着用が推奨される。運転者に対 する効果的な外傷予防教育や政府機関の法的規制も, ジェットスキーによる損傷回避のために考慮されるべきで ある。

（日救急医会誌 $2009 ； 20 ： 232-6$ )

キーワード：直腸穿孔，肛門損傷，人工肛門，敗血症，腹膜炎

滋賀医科大学外科学講座

著者連絡先： $\overline{7} 520-2192$ 滋賀県大津市瀬田月輪町／原稿受理日：2008 年 12 月 5 日（08-091） 